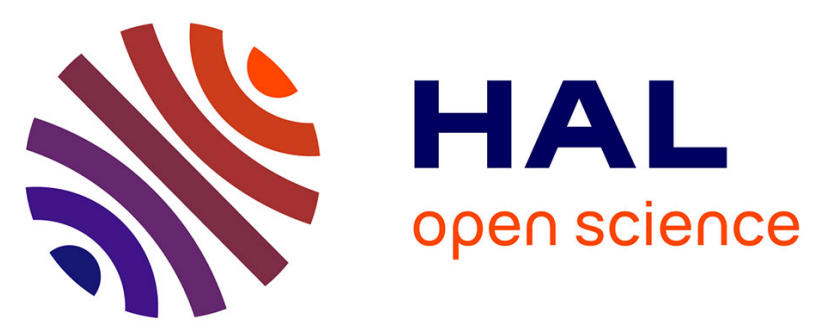

\title{
A role for MC3R in modulating lung inflammation
}

Stephen J. Getting, Yanira Riffo-Vasquez, Simon Pitchford, Magdalena

Kaneva, Paolo Grieco, Clive P. Page, Mauro Perretti, Domenico Spina

\section{To cite this version:}

Stephen J. Getting, Yanira Riffo-Vasquez, Simon Pitchford, Magdalena Kaneva, Paolo Grieco, et al.. A role for MC3R in modulating lung inflammation. Pulmonary Pharmacology \& Therapeutics, 2008, 21 (6), pp.866. 10.1016/j.pupt.2008.09.004 . hal-00499161

\section{HAL Id: hal-00499161 https://hal.science/hal-00499161}

Submitted on 9 Jul 2010

HAL is a multi-disciplinary open access archive for the deposit and dissemination of scientific research documents, whether they are published or not. The documents may come from teaching and research institutions in France or abroad, or from public or private research centers.
L'archive ouverte pluridisciplinaire HAL, est destinée au dépôt et à la diffusion de documents scientifiques de niveau recherche, publiés ou non, émanant des établissements d'enseignement et de recherche français ou étrangers, des laboratoires publics ou privés. 


\section{Author's Accepted Manuscript}

A role for MC3R in modulating lung inflammation

Stephen J. Getting, Yanira Riffo-Vasquez, Simon Pitchford, Magdalena Kaneva, Paolo Grieco, Clive P. Page, Mauro Perretti, Domenico Spina

PII: $\quad$ S1094-5539(08)00092-8

DOI: $\quad$ doi:10.1016/j.pupt.2008.09.004

Reference: $\quad$ YPUPT 860

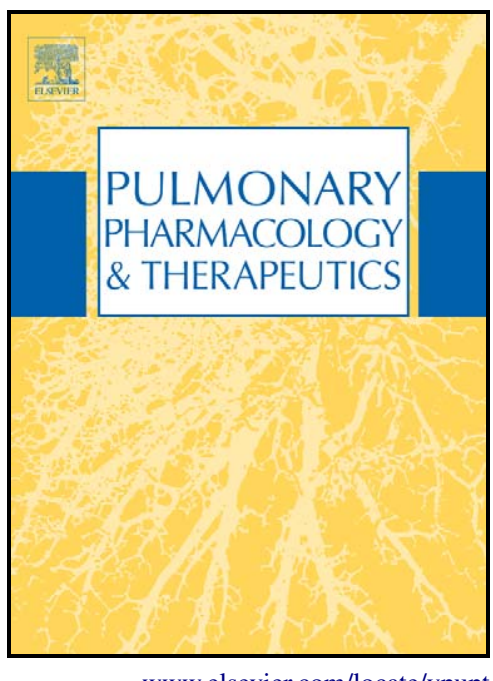

www.elsevier.com/locate/ypupt

To appear in: Pulmonary Pharmacology \& Therapeutics

Received date: 28 July 2008

Revised date: 18 September 2008

Accepted date: 24 September 2008

Cite this article as: Stephen J. Getting, Yanira Riffo-Vasquez, Simon Pitchford, Magdalena Kaneva, Paolo Grieco, Clive P. Page, Mauro Perretti and Domenico Spina, A role for MC3R in modulating lung inflammation, Pulmonary Pharmacology \& Therapeutics (2008), doi:10.1016/j.pupt.2008.09.004

This is a PDF file of an unedited manuscript that has been accepted for publication. As a service to our customers we are providing this early version of the manuscript. The manuscript will undergo copyediting, typesetting, and review of the resulting galley proof before it is published in its final citable form. Please note that during the production process errors may be discovered which could affect the content, and all legal disclaimers that apply to the journal pertain. 


\section{A role for $M C 3 R$ in modulating lung inflammation}

Stephen J. Getting, Yanira Riffo-Vasquez, Simon Pitchford, Magdalena Kaneva, Paolo Grieco, Clive P. Page, Mauro Perretti and Domenico Spina

School of Biosciences, Department of Human and Health Sciences, University of Westminster, 115 New Cavendish Street, London, W1W 6UW, United Kingdom (SJG, MK)

Sackler Institute of Pulmonary Pharmacology, School of Biomedical and Health Science, King's College London, $5^{\text {th }}$ Floor Hodgkin Building, Guy's Campus, London SE1 1UL (YRV, SP, CP, DS)

Department of Pharmaceutical Chemistry and Toxicology, Universitá di Napoli, 80131 Naples, Italy (PG).

The William Harvey Research Institute, Bart's and the London, Queen Mary School of Medicine and Dentistry, Charterhouse Square, London EC1M 6BQ, United Kingdom. (MP) 


\section{Abstract}

In this study we set out to ascertain whether melanocortin peptides could be potential therapeutic agents in an allergic and non-allergic model of lung inflammation by identifying the receptor(s) involved using a molecular, genetic and pharmacological approach. Western blot analyses revealed expression of the melanocortin receptor (MCR) type 1 and 3 on alveolar macrophages from wild-type mice. Alveolar macrophage incubation with the selective MC3R agonist $\left[\mathrm{D}-\mathrm{TRP}^{8}\right]-\gamma-$ $\mathrm{MSH}$ and pan agonist $\alpha-\mathrm{MSH}$ but not the selective MC1R agonist MS05, led to an increase in cAMP in wild-type macrophages. This increase occurred also in macrophages taken from recessive yellow (e/e) (bearing a mutant and inactive MC1R,) mice but not from MC3R null mice.

In an allergic model of inflammation, the pan-agonist $\alpha-\mathrm{MSH}$ and selective MC3R agonist $\left[\mathrm{D}-\mathrm{TRP}^{8}\right]-\gamma-\mathrm{MSH}$ displayed significant attenuation of both eosinophil and lymphocyte accumulation but not IL-5 levels in wild-type and recessive yellow e/e mice. However in MC3R null mice, $\alpha-M S H$ failed to cause a significant inhibition in these parameters, highlighting a preferential role for MC3R in mediating the antiinflammatory effects of melanocortins in this model. Utilising a non-allergic model of LPS induced lung neutrophilia, the pan-agonist $\alpha-M S H$ and selective MC3R agonist $\left[\mathrm{D}-\mathrm{TRP}^{8}\right]-\gamma-\mathrm{MSH}$ displayed significant attenuation of neutrophil accumulation and inhibition of TNF- $\alpha$ release. Thus, this study highlights that melanocortin peptides inhibit leukocyte accumulation in a model of allergic and non-allergic inflammation and this protective effect is associated with activation of the MC3R. The inhibition of leukocyte accumulation is via inhibition of TNF- $\alpha$ in the non-allergic model of inflammation but not IL-5 in the allergic model. This data has highlighted the potential 
for selective MC3R agonists as novel anti-inflammatory therapeutics in lung inflammation.

Key words:

Anti-inflammation; Cell-Trafficking; leukocytes; melanocortin; cytokines; GPCR 
The trafficking of leukocytes from blood vessels to the site of infection is a hallmark of inflammatory disease and occurs following exposure to allergens and infectious agents [1]. This response occurs promptly (pro-inflammation) and needs to be regulated in a controlled manner (anti-inflammation) ensuring that homeostasis is restored to the tissue in a time-dependent manner [2]. The host-inflammatory response is driven by pro-inflammatory mediators including the cytokines IL-1 $\beta$, TNF$\alpha$ and IL-8 (CXCL8), upregulation of adhesion molecules and proteolytic enzymes leading to the migration of leukocytes to the site of inflammation for $\mathrm{TH} 1$ responses [3]. Whilst for $\mathrm{TH} 2$ responses in the asthmatic lung activation of integrins on circulating eosinophils followed by tethering and rolling on bronchial endothelial cells [4] with increases in IL-4 and IL-5 leading to further activation and subsequent transmigration [5]. To aid in the resolution of this response a number of endogenous modulators of inflammation are produced including annexin 1 [6], galectin [7], lipoxins [8] and melanocortins $[9,10]$ and these have been shown to inhibit leukocyte trafficking and help prevent tissue damage.

Melanocortin peptides (e.g. $\alpha$-melanocortin stimulating hormone, $\alpha-\mathrm{MSH}$ ) are derived from a larger precursor molecule called the pro-opiomelanocortin (POMC) gene $[9$, 10] and exert their biological effect via activation of a sub-group of G-protein coupled receptor, termed melanocortin receptors (MCR). To date five MCRs have been identified and they are all positively coupled to adenylate cyclase, signaling via protein kinase with agonism at these receptors leading to increases in intracellular cAMP [11]. Melanocortin peptides have long been reported to possess antiinflammatory effects in many experimental models of acute [12-14] and chronic inflammation, including inflammatory bowel disease [15], joint arthritis [16,17] and 
systemic inflammation (endotoxemia) [18] as well as allergic inflammation [19]. Melanocortin peptides have been shown to down-regulate nuclear factor-kappa beta activation and consequent cytokine synthesis within the first few hours of treatment $[20,21]$ and at later time points $(>8 \mathrm{~h})$ induce the anti-inflammatory protein hemeoxygenase 1 [22] and IL-10 [24]. Only one study has so far addressed the role of $\alpha-\mathrm{MSH}$ in modulating eosinophil accumulation levels in a murine model of allergic airway disease [19]: $\alpha-\mathrm{MSH}$ treatment of allergic mice led to a significant reduction in inflammation and this protective effect was associated with augmented IL-10 production. The pivotal role of IL-10 was further substantiated using IL-10 null mice where $\alpha-\mathrm{MSH}$ was inactive [19].

The present study was undertaken to further investigate the potential of melanocortin peptides in murine models of allergic and non-allergic inflammation. In vitro analysis identified the presence of two receptors (MC1 and MC3R) on alveolar macrophages and indicated that the MC3R was functionally active. Importantly, in vivo experimentation confirmed that melanocortin peptides are efficacious in inhibiting leukocyte accumulation and utilisation of selective pharmacological agents and genetically modified mice highlighted a preferential role for MC3R in mediating the protective effects of the melanocortin peptides in this allergic model of lung inflammation. Finally to determine whether the effects in the lung could be extrapolated to non-allergic inflammation, the pan agonist $\alpha-\mathrm{MSH}$ and selective MC3R agonist [D-TRP $\left.{ }^{8}\right]-\gamma-\mathrm{MSH}$ modulated LPS induced neutrophil accumulation and TNF- $\alpha$ release. These data indicate that melanocortin peptides are able to modulate both allergic and non-allergic inflammation within the lung. 


\section{Materials and methods}

\section{MCR protein expression}

Alveolar macrophage $(\mathrm{M} \varnothing)$ pattern of expression for MC1R and MC3R protein was determined as recently described $[22,24]$ from naïve mice. Following electrophorysis in a $10 \%$ polyacrylamide gel, membranes were blocked overnight in blocking solution containing $5 \%$ non-fat milk solution in Tris buffer saline containing $0.1 \%$ Tween-20 followed by anti-MC3R (1:2000) [22] or anti-MC1R (1:2000 Sigma-Aldrich, Dorset, UK) rabbit serum incubation in blocking solution. The antibodies used in this study have been reported by the manufacturer to show no cross-reactivity with other MCR (data furnished by Sigma-Aldrich, Dorset, UK). Non-specific antibody binding was washed prior to the addition of goat anti-rabbit antibody (1:2000). The membranes were further washed and specific antibody binding was detected by enhanced chemiluminescence system. Following detection, bound antibodies were removed by incubating the membranes in acidic Glycine solution (100 mM Glycine, $\mathrm{pH} 2.5)$. The membranes were subsequently re-probed for the detection of $\alpha$-Tubulin $(1: 5,000$; Sigma-Aldrich Co. Ltd. Gillingham, UK). Densitometry analysis was performed using Image J software.

\section{Intracellular cAMP accumulation}

Alveolar M $\varnothing\left(1 \times 10^{5}\right.$ per well) were obtained from WT, recessive yellow e/e and MC3R mutant mice anaesthetized with urethane $(2 \mathrm{~g} / \mathrm{kg}$ i.p.; Sigma Chemical Co, UK). A cannula was inserted into the exposed trachea of anaesthetized mice where three $0.5 \mathrm{~mL}$ aliquots of warm sterile saline were injected into the lung and bronchoalveolar lavage fluid was collected. An aliquot $(90 \mu \mathrm{L})$ of Turks solution 
$(0.01 \%$ crystal violet in $3 \%$ acetic acid) was added to $10 \mu \mathrm{L}$ of bronchoalveolar lavage fluid and the total number of macrophages enumerated with an improved Neubauer haemocytometer. The cells were then incubated in serum free RPMI-1640 media containing $1 \mathrm{mM}$ isobutylmethylxanthine (IBMX, Sigma-Aldrich, Dorset, UK) and $1-30 \mu \mathrm{g} / \mathrm{ml}$ selective MC3R agonist $\left[\mathrm{D}-\mathrm{TRP}^{8}\right]-\gamma-\mathrm{MSH}$, pan agonist $\alpha-\mathrm{MSH}, 1-100$ $\mu \mathrm{g} / \mathrm{ml}$ selective MC1R agonist MS05 (kindly provided by Helgi Schioth, Uppsala University, Sweden) or the direct adenylate cyclase forskolin $(3 \mu \mathrm{M})$ (Sigma-Aldrich, Dorset, UK). Cells were washed after $30 \mathrm{~min}$ at $37^{\circ} \mathrm{C}$ and lysed, and cAMP levels in cell lysates determined with a commercially available enzyme immunoassay (Amersham Ltd, Little Chalfont, Buckinghamshire, UK) using a standard curve constructed with 0-3,200 fmol/ml cAMP [12].

\section{Drug Treatment}

Mice received $\alpha-\mathrm{MSH}$, the selective MC3R agonist $\left[\mathrm{D}-\mathrm{TRP}^{8}\right]-\gamma-\mathrm{MSH}[24,25]$ at 1 or $5 \mathrm{mg} / \mathrm{kg}$. i.p. $0.2 \mathrm{ml}$ in saline) or dexamethasone $2.5 \mathrm{mg} / \mathrm{kg}$ (Sigma-Aldrich, Dorset, UK), 5 minutes prior to each challenge in the ovalbumin allergic model whilst control animals received saline. In the LPS lung inflammation model mice received $\alpha-M S H$ (5 mg/kg), the selective MC3R agonist [D-TRP $\left.{ }^{8}\right]-\gamma-M S H[24,25]$ at $1 \mathrm{mg} / \mathrm{kg}$. i.p. $0.2 \mathrm{ml}$ in saline), 60 minutes prior to LPS intranasal challenge using a previously published methododlogy [26], whilst control animals received saline. $\alpha-\mathrm{MSH}$ was purchased from Bachem Ltd. (Saffron Walden, Essex, UK) whilst $\left[\mathrm{D}-\mathrm{TRP}^{8}\right]-\gamma-\mathrm{MSH}$ was synthesised by Dr Paolo Grieco as previously described [24,25], peptides were stored at $-20^{\circ} \mathrm{C}$ prior to use, and dissolved in sterile PBS ( $\left.\mathrm{pH} 7.4\right)$. 


\section{Allergic model: Immunization protocol}

Mice (20-25g) were immunised via intra-peritoneal injection (i.p.) on days 0 and 7 with OVA (grade V, Sigma), $10 \mu \mathrm{g} /$ mouse, in $0.4 \mathrm{ml} 0.1 \mathrm{M} \mathrm{Al}(\mathrm{OH})_{3}$ in saline. Sham animals received alum alone. All mice including sham were subsequently exposed to aersolised OVA ( $3 \%$ solution) or saline for a single 25 minute periods, once per day, on days 14,15 , and 16 . Bronchoalveolar lavage was performed on mice 24 hours after the last OVA challenge on day 16 [27].

Breeding pairs of the MC3R null colony backcrossed for 6 generations into a homogenous C57 Bl.6 background [28] were kindly donated by $\mathrm{Dr} \mathrm{H}$ Chen (Merck Research Laboratories, Rahway, NJ, USA). Recessive yellow e/e (mutant MC1R mice) which display a frameshift mutation in the MC1R gene at position 549; the outcome is a receptor with a premature termination in the fourth trans-membrane domain, thus unable to couple to adenylate cyclase and activate cAMP synthesis. These were kindly provided by Dr Nancy Levin, Trega Biosciences, San Diego, USA) and have a C57 BI.6 background [14]. Male C57 BI.6 (wild-type) mice (20-22 g body weight) were obtained from a local supplier. Mice were maintained on a standard chow pellet diet with tap water ad libitum using a 12:00 h light/dark cycle. Animal experimental work was performed according to Home Office regulations (Guidance on the Operation of Animals, Scientific Procedures Act, 1986).

\section{Broncho-alveolar lavage}

Twenty-four hours after the last aerosolized challenge with either saline or ovalbumin, mice were anaesthetized with urethane (2 g/kg i.p.; Sigma Chemical Co, UK) and a cannula was inserted into the exposed trachea of anaesthetized mice 
where three $0.5 \mathrm{~mL}$ aliquots of warm sterile saline were injected into the lung and bronchoalveolar lavage fluid was collected. An aliquot $(90 \mu \mathrm{L})$ of Turks solution $(0.01 \%$ crystal violet in $3 \%$ acetic acid) was added to $10 \mu \mathrm{L}$ of bronchoalveolar lavage fluid and the total number of cells enumerated with an improved Neubauer haemocytometer. For differential cell counts, cytospin preparations were prepared from aliquots of BAL fluid $(100 \mu \mathrm{L})$ centrifuged at $300 \mathrm{~g}$ for $1 \mathrm{~min}$ using a Shandon Cytospin 2 (Shandon Southern Instruments, Sewickley, PA, USA) at room temperature. Cells were then stained with Diff Quik (Gamidor) And a total of 200 cells were counted for determination of monocyte/ macrophage, lymphocyte, neutrophil, eosinophil population fractions using standard morphological criteria [27, 29].

Mice (20-25g) were immunised via intra-peritoneal injection (i.p.) on days 0 and 7 with OVA (grade $\mathrm{V}$, Sigma), $10 \mu \mathrm{g} / \mathrm{mouse}$, in $0.4 \mathrm{ml} 0.1 \mathrm{M} \mathrm{Al}(\mathrm{OH})_{3}$ in saline. Sham animals received alum alone. All mice including sham were subsequently exposed to aersolised OVA ( $3 \%$ solution) or saline for a single 25 minute periods, once per day, on days 14,15 , and 16 . Bronchoalveolar lavage was performed on mice 24 hours after the last OVA challenge on day 16 [27].

Breeding pairs of the MC3R null colony backcrossed for 6 generations into a homogenous C57 Bl.6 background [28] were kindly donated by $\mathrm{Dr} \mathrm{H}$ Chen (Merck Research Laboratories, Rahway, NJ, USA). Recessive yellow e/e (mutant MC1R mice) which display a frameshift mutation in the MC1R gene at position 549; the outcome is a receptor with a premature termination in the fourth trans-membrane domain, thus unable to couple to adenylate cyclase and activate cAMP synthesis. 
These were kindly provided by Dr Nancy Levin, Trega Biosciences, San Diego, USA) and have a C57 BI.6 background [14]. Male C57 BI.6 (wild-type) mice (20-22 g body weight) were obtained from a local supplier. Mice were maintained on a standard chow pellet diet with tap water ad libitum using a 12:00 h light/dark cycle. Animal experimental work was performed according to Home Office regulations (Guidance on the Operation of Animals, Scientific Procedures Act, 1986).

\section{Non-allergic LPS-induced airway inflammation:}

Mice were administered $50 \mu \mathrm{l}$ of a $0.01 \mathrm{mg} / \mathrm{ml}$ solution of LPS (E.coli $0111: B 4$ ) in saline via the intranasal route while lightly anesthetized with $5 \%$ halothane. To assess the effects of the melanocortin peptides $\alpha-\mathrm{MSH}(5 \mathrm{mg} / \mathrm{kg}$ i.p.) and the selective MC3R agonist [D-TRP ${ }^{8}$ - $\gamma-\mathrm{MSH}$ (1 mg/kg i.p.) were administered $1 \mathrm{~h}$ prior to LPS. All mice were killed (as described above) 4h after LPS administration and bronchoalveolar lavage (BAL) was performed as described above [27]. Total cell counts and differential counts of stained cytospin preparations was used to determine the total number of neutrophils recovered from the BAL as described above. Lavage fluid was then analysed for TNF- $\alpha$ via a commercially available ELISA (R\&D systems, Oxon, UK) according to the manufacturers instructions. 


\section{ELISA measurements:}

Murine IL-5 and TNF- $\alpha$ levels in the bronchoalveolar lavage (BAL) fluids were quantified with Quantikine ${ }^{\mathrm{TM}}$ ELISA purchased from R\&D Systems (Oxfordshire, UK). The ELISAs showed negligible $(<1 \%)$ cross-reactivity with several murine cytokines and chemokines (data as furnished by the manufacturer).

\section{Statistical analysis}

All values are expressed as mean \pm SEM, with an $n$ number of mice for the in vivo experiments. For in vitro analysis, experiments were repeated at least with three distinct preparations (i.e. RT-PCR and western blotting analyses). Statistical analysis was assessed either by Mann Whitney $U$ test (for blot analyses) or one-way ANOVA followed by Bonferroni test (for the in vivo experimentation). In all cases, a probability $p$ value less than 0.05 was considered significant to reject the null hypothesis [30]. 


\section{Results}

\section{Alveolar macrophages express functional MC3R}

Murine alveolar $M \varnothing$ expressed MC1R and MC3R protein (Figure 1a), densitometry analysis showed that MC3R was expressed more predominately than MC1R on alveolar macrophages (Figure 1b). We next evaluated whether these receptors were functionally active, addition of the pan-MCR agonist $\alpha-\mathrm{MSH}(1-30 \mu \mathrm{g} / \mathrm{ml})$, led to an increase in cAMP accumulation within alveolar macrophages taken from wild-type mice with a maximal increase of $185 \pm 33 \mathrm{fmol} / \mathrm{well}\left({ }^{*} \mathrm{P}<0.05\right)$ at $10 \mu \mathrm{g} / \mathrm{ml}$. The positive control forskolin caused a significant increase in cAMP with $272 \pm 61$ $\mathrm{fmol} /$ well being detected compared to $64 \pm 7 \mathrm{fmol} /$ well in vehicle treated cells. We next sought to investigate whether selective compounds directed at the MC1R (MS05) or the MC3R ([D-TRP $\left.\left.{ }^{8}\right]-\gamma-\mathrm{MSH}\right)$ could cause activation of the MC1R and MC3R. The selective MC1R agonist MS05 $(1-30 \mu \mathrm{g} / \mathrm{ml})$ failed to provoke cAMP accumulation at any of the concentrations tested. A different scenario was observed with the selective MC3R agonist $\left[\mathrm{D}-\mathrm{TRP}^{8}\right]-\gamma-\mathrm{MSH}(1-30 \mu \mathrm{g} / \mathrm{ml})$ that caused a significant increase in cAMP accumulation at $3 \mu \mathrm{g} / \mathrm{ml}$, whereas lower and higher concentrations failed to evoke an increase in cAMP accumulation (Figure 2).

Given that melanocortin peptides could induce cAMP in wild-type alveolar macrophages we sought whether they were active in alveolar macrophages obtained from MC1R mutant (recessive yellow e/e) or MC3R null mice. Again, the pan agonist $\alpha-\mathrm{MSH}$ caused a significant increase in cAMP accumulation with a maximal increase occurring at 10 and $30 \mu \mathrm{g} / \mathrm{ml}$ in recessive yellow e/e macrophages; in contrast, no effect on alveolar macrophages taken from MC3R null mice (Table 1). The selective MC3R agonist $\left[\mathrm{D}-\mathrm{TRP}^{8}\right]-\gamma-\mathrm{MSH}$ caused a significant increase in cAMP at $3 \mu \mathrm{g} / \mathrm{ml}$ in 
recessive yellow e/e macrophages but it had no effect on MC3R null macrophages (Table 1).

\section{Effects of [D-TRP $\left.{ }^{8}\right]-\gamma-M S H$ and $\alpha-M S H$ in a model of allergic inflammation in}

\section{wild-type mice.}

Since melanocortin peptides could cause an increase in cAMP accumulation in alveolar macrophages we evaluated their therapeutic potential in a model of allergic inflammation. In line with previous studies [29], OVA challenge following immunization led to an intense accumulation of eosinophils to the airways, reliably assessed $24 \mathrm{~h}$ after the last challenge (Figure 2a). Pre-treatment of wild-type mice with $\alpha-\mathrm{MSH}$ at 1 and $5 \mathrm{mg} / \mathrm{kg}$ led to a $50 \%$ and $69 \%\left({ }^{*} \mathrm{P}<0.05\right)$ reduction in eosinophil accumulation respectively whilst the positive control dexamethasone, given at $2.5 \mathrm{mg} / \mathrm{kg}$, led to $98 \%\left({ }^{*} \mathrm{P}<0.05\right)$ reduction (Figure $\left.3 a\right)$. The selective MC1R agonist MS05 was not evaluated as it failed to cause an accumulation of cAMP. The selective $\mathrm{MC} 3 \mathrm{R}$ agonist $\left[\mathrm{D}-\mathrm{TRP}^{8}\right]-\gamma-\mathrm{MSH}$, administered at $1 \mathrm{mg} / \mathrm{kg}$, significantly attenuated eosinophil accumulation $\left(-66 \%\right.$; $\left.{ }^{*} \mathrm{P}<0.05\right)$. At the higher dose of $5 \mathrm{mg} / \mathrm{kg}$ $\left[\mathrm{D}-\mathrm{TRP}^{8}\right]-\gamma-\mathrm{MSH}$ provoked a modest non-significant reduction. This inhibition in eosinophil accumulation was not associated with reduction in BAL fluid IL-5 levels, sham levels were below the detection limit of the assay (Table 2). We next monitored potential effects on lymphocyte accumulation, OVA challenge caused a significant increase in lymphocyte accumulation $\left(8.5 \pm 1.9 \times 10^{3} / \mathrm{ml}\right)$; dexamethasone reduced this marker of lung inflammation by $96 \%$ by dexamethasone whilst $\alpha-\mathrm{MSH}$ caused a reduction of $95 \%$ at $5 \mathrm{mg} / \mathrm{kg}$ and $46 \%$ at $1 \mathrm{mg} / \mathrm{kg}$. The selective MC3R agonist [D$\left.\mathrm{TRP}^{8}\right]-\gamma-\mathrm{MSH}$ was without significant effect at $5 \mathrm{mg} / \mathrm{kg}$ whilst at $1 \mathrm{mg} / \mathrm{kg}$ caused $80 \%$ reduction in lymphocyte accumulation $\left({ }^{*} \mathrm{P}<0.05, \mathrm{n}=5\right.$; Figure $\left.3 b\right)$. No detection of 
eosinophils or lymphocytes was measured in sham immunized mice (Figure $3 a$ and b).

Effects of [D-TRP $\left.{ }^{8}\right]-\gamma-$ MSH and $\alpha$-MSH in a model of allergic inflammation in recessive yellow e/e mice and MC3R null mice.

Since MC1 and MC3R were found to be expressed on alveolar macrophages we used a genetic approach to ascertain whether these in vitro findings were translated into an in vivo setting. $\alpha-\mathrm{MSH}(5 \mathrm{mg} / \mathrm{kg})$ and dexamethasone $(2.5 \mathrm{mg} / \mathrm{kg}$ ) was evaluated in both strains, whilst $\left[\mathrm{D}^{-T R P^{8}}\right]-\gamma-\mathrm{MSH}(1 \mathrm{mg} / \mathrm{kg})$ was only used in the recessive yellow e/e mouse. No detection of eosinophils or lymphocytes was measured in sham immunized recessive yellow e/e mice (Figure 4a and b).

Dexamethasone caused a $95 \%$ an $86 \%$ reduction in eosinophils accumulation present in bronchoalveolar lavage in recessive yellow mice (Figure 4a) and MC3R null mice (Figure 5a) respectively. The pan-agonist $\alpha-\mathrm{MSH}$ significantly attenuated eosinophil accumulation in recessive yellow e/e mice by $63 \%$ (Figure $4 a$ ) but not in MC3R null mice with a non-significant $23 \%$ reduction being observed (Figure $5 a$ ). The selective MC3R agonist [D-TRP $\left.{ }^{8}\right]-\gamma-M S H$ caused an $88 \%\left({ }^{*} P<0.05, n=5\right)$ reduction in eosinophil number in lavage fluid from recessive yellow e/e mice (Figure 4a) but was not evaluated in MC3R null mice as previously we have shown it to be inactive in these mice. Once again no effect was observed on IL-5 levels in the BAL fluid from either strain, sham levels were below the detection limit of the assay (Table 2). Given the pivitol lymphocytes play in this pathology the ability of the melanocortins to modulate migrating lymphocytes was evaluated. A similar profile to that seen with eosinophil accumulation was observed with dexamethasone causing a 
$-92 \%$ and $87 \%$ reduction in recessive yellow e/e (Figure $4 \mathrm{~b}$ ) and MC3R null mice

(Figure $5 \mathrm{~b})$ respectively. $\alpha-\mathrm{MSH}(5 \mathrm{mg} / \mathrm{kg})$ and $\left[\mathrm{D}-\mathrm{TRP}{ }^{8}\right]-\gamma-\mathrm{MSH}(1 \mathrm{mg} / \mathrm{kg})$ caused a significant $87 \%$ and $75 \%\left({ }^{*} \mathrm{P}<0.05, \mathrm{n}=5\right)$ reduction in lymphocyte accumulation respectively in recessive yellow e/e mice (Figure $4 b$ ), whilst $\alpha$-MSH caused a nonsignificant reduction in MC3R null mice (Figure 5b). No detection of eosinophils or lymphocytes was measured in sham MC3R null immunized mice (Figure 5a and b).

\section{Effects of [D-TRP $\left.{ }^{8}\right]-\gamma-\mathrm{MSH}$ and $\alpha-\mathrm{MSH}$ in a model of non-allergic LPS induced}

\section{neutrophilia.}

Since the pan-agonist $\alpha-M S H$ and selective MC3R agonist $\left[\mathrm{D}-\mathrm{TRP}^{8}\right]-\gamma-\mathrm{MSH}$ were effective in modulating eosinophil and lymphocyte accumulation, in a model of allergic inflammation, we evaluated their effects in a non-allergic model of neutrophilia. $\alpha-\mathrm{MSH}(5 \mathrm{mg} / \mathrm{kg})$ and $\left[\mathrm{D}-\mathrm{TRP}^{8}\right]-\gamma-\mathrm{MSH}(1 \mathrm{mg} / \mathrm{kg})$ caused a significant reduction in neutrophil accumulation with a 42 and $43 \%\left({ }^{*} \mathrm{P}<0.05, \mathrm{n}=6\right)$ reduction respectively (Figure 6a). The selective $M C 3 R$ agonist $\left[\mathrm{D}-\mathrm{TRP} \mathrm{P}^{8}\right]-\gamma-\mathrm{MSH}$ and pan agonist $\alpha-\mathrm{MSH}$ were then evaluated for inhibition of TNF- $\alpha$ causing a $48 \%\left({ }^{*} \mathrm{P}<0.05\right.$, $n=6)$ and $39 \%\left({ }^{*} P<0.05, n=6\right)$ (Figure 6b). 


\section{Discussion}

In this study we have challenged the hypothesis that targeting melanocortin receptors could provide a novel therapeutic lead for modulating allergic and nonallergic lung inflammation. We have done so by using a pharmacological, genetic and molecular approach utilising the selective MC3R ligand [D-TRP $\left.{ }^{8}\right]-\gamma-\mathrm{MSH},[24$, 25], MC3R deficient mice [28, 31] and the recessive yellow e/e (bearing a nonfunctional MC1R) mouse [14]. This study has focused on the MC1 and 3R given the wealth of data highlighting that both these receptors are involved in modulating the host inflammatory response [10] other MCR were not evaluated in this study due to the fact that they haven't been implicated in modulating peripheral inflammation. However a role for MC4R in modulating brain inflammation has recently been proposed [32]. More importantly melanocortin peptides display anti-migratory effects in wild-type and recessive yellow e/e (mutant MC1R) mice but not in the MC3R null mouse, indicating a role for the MC3R in mediating the anti-inflammatory effects of the melanocortins in this model of allergic inflammation. Utilising a non-allergic LPS model of lung inflammation, neutrophil accumulation and TNF- $\alpha$ levels were modulated in the presence of both $\alpha-\mathrm{MSH}$ and $\left[\mathrm{D}-\mathrm{TRP}^{8}\right]-\gamma-\mathrm{MSH}$. These new data add strength to the hypothesis that a tonic inhibitory signal could be activated by MC3R agonists and exploited for the development of novel therapeutics.

Melanocortins anti-inflammatory effects have been partially unravelled [18, 31] whilst historically the parent hormone, adrenocorticotrophin has been used clinically [33]. However the identification by Lipton and colleagues that $\alpha-\mathrm{MSH}$, which corresponds to the first 13 amino acid of adrenocorticotrophin, also display anti-inflammatory activities in several pre-clinical models, has renewed interest in this field. Since the 
melanocortins exert their biological effect through activation of specific seven transmembrane GPCR's, identification of the physiological role played by each of these has raised hopes for innovative drug discovery [10].

We have previously shown that rodent knee joint and peritoneal macrophages express MC1R and MC3R $[16,22]$ a cell type that responded with down-regulatory events to the addition of non-selective melanocortins. The expression of MC3R on $\mathrm{M} \varnothing$ membrane protrusions was confirmed by immuno-gold labelling utilising electron microscopy [14]. Here we have been able to show that alveolar macrophages expressed both MC1R and MC3R, whilst detection of MC1R is in agreement with a previous study [19] the finding of MC3R is novel. The selective MC3R agonist [D$\left.\mathrm{TRP}^{8}\right]-\gamma-\mathrm{MSH}$ could activate a classical post-receptor signalling in wild-type alveolar $M \varnothing$, an effect not elicited by the selective MC1R agonist MS05 [14]. This lack of effect of the selective MC1R agonist MS05 is not altogether surprising as previously we have shown that between 1-100 $\mu \mathrm{g} /$ mouse in C57 BI.6 and also in mice bearing a non-functional MC1R (recessive yellow e/e mice) there is no inhibition in leukocyte accumulation in acute models of inflammation [14]. Thus, we cannot rule out an antiinflammatory effect of MS05 in this model, it is highly unlikely since MS05 did not increase cAMP in vitro and has in the past failed to modulate the host inflammatory response. Another potential explanation could be that only $10 \%$ of alveolar macrophages express the MC1R [19] and thus their may be insufficient receptors available to elicit a measurable response in this system. The effects observed with the selective MC3R agonist $\left[\mathrm{D}-\mathrm{TRP}^{8}\right]-\gamma-\mathrm{MSH}$ are in contrast to our previous findings indicating a "bell-shaped" response effect with this peptide in peritoneal macrophages elicited from C57 Bl.6 mice [24] and may suggest that alveolar and 
peritoneal macrophages respond in different ways to melanocortin peptides. The data highlights that MC3R plays a pivotal role in modulating the allergic inflammatory response and in vitro data could suggest a role for the resident macrophage in mediating the anti-inflammatory effects of these peptides. However it's not possible to rule out involvement of endothelial and epithelial cells in this process given that they express melanocortin receptors [24].

We next evaluated the role of the pan-agonist $\alpha-M S H$ and $\left[\mathrm{D}-\mathrm{TRP}^{8}\right]-\gamma-\mathrm{MSH}$ in a murine model of allergic inflammation. Sensitisation of mice with OVA followed by repeated exposure to ovalbumin resulted in a significant increase in total cells recovered from bronchoalveolar lavage in a similar magnitude reported previously in C57 Bl.6 mice [33]. The cell infiltrate was predominantly monocytic in shamimmunized mice. However, a significant increase in the percentage of eosinophils and lymphocytes was observed in immunized mice following aerosol exposure to ovalbumin, consistent with previous studies in this strain of mice [34]. The allergic inflammatory response to ovalbumin was mildly exacerbated ( $25 \%$; not significant) in recessive yellow e/e and MC3R null mouse, indicating that under the present experimental conditions, endogenously released melanocortins might not interfere with the process of allergen sensitisation or to the inflammatory response per se. In contrast, and more clearly, MC3R is a critical anti-inflammatory signalling pathway for melanocortins, and in the absence of this receptor, the anti-inflammatory activity of melanocortin peptides was abolished.

We next evaluated anti-inflammatory agents in this allergic model, with the glucocorticosteroid dexamethasone causing a near total abrogation in leukocyte 
accumulation in wild-type mice. The pan agonist $\alpha-M S H$, known not to release corticosterone $[12,14]$ caused a significant inhibition at both 1 and $5 \mathrm{mg} / \mathrm{kg}$ a dose range previously shown to modulate eosinophil accumulation in Balb/C and C57 BI.6 mice [19]. However we have been able to show that there was a reduction in lymphocyte accumulation, a cell type shown to be pivotal for the development of allergic inflammation [35]. In contrast to our findings, a previous study has shown that melanocortin peptides did not suppress lymphocyte recruitment to the airways in female allergic balb/c mice despite, impairing eosinophil recruitment to the airways [19]. The apparent discrepancy seen could be due to the strain of mice used since a significant reduction was seen at the same dose of $1 \mathrm{mg} / \mathrm{kg}$ and a near total abrogation was observed at $5 \mathrm{mg} / \mathrm{kg} \alpha-\mathrm{MSH}$. This data highlighted that this model of allergic inflammation was susceptible to treatment with melanocortins but did not allow us to address the underlying question of this study, of whether MC1R or MC3R was responsible for modulating the allergic inflammatory response in this strain of mouse.

Pharmacological agents such as the selective MC3R agonist $\left[\mathrm{D}-\mathrm{TRP}^{8}\right]-\gamma-\mathrm{MSH}$ have been developed to allow for a better understanding of the role played by each receptor [10]. [D-TRP $\left.{ }^{8}\right]-\gamma-\mathrm{MSH}(1 \mathrm{mg} / \mathrm{kg})$ inhibited both eosinophil and lymphocyte accumulation, whilst a higher dose failed to modulate the inflammatory response. This lack of effect at the highest dose is in agreement with previous pharmacological studies where melanocortins display a bell shaped dose response curve [12]. Given that $\alpha-\mathrm{MSH}(5 \mathrm{mg} / \mathrm{kg})$ and $\left[\mathrm{D}-\mathrm{TRP}^{8}\right]-\gamma-\mathrm{MSH}(1 \mathrm{mg} / \mathrm{kg})$ displayed potent anti-migratory activity in this model we next used the recessive yellow e/e (mutant MC1R) [14] and the MC3R null mouse [24]. $\alpha-M S H$ and [D-TRP $\left.{ }^{8}\right]-\gamma-M S H$ caused significant reduction 
in both eosinophil and lymphocyte accumulation in the recessive yellow e/e mouse, whilst in the MC3R null mouse a non-significant reduction was observed with $\alpha-M S H$. These effects, would suggest a preferential role for the MC3R in mediating the antimigratory effects of the melanocortins. These data provide a strong validation to our working hypothesis that signalling via the MC3R subtype is responsible for mediating the anti-inflammatory actions of this class of peptides. Finally we evaluated whether the anti-inflammatory effect of these peptides could be attributed to non-allergic models of inflammation. The ability of melanocortin peptides to modulate LPS lung induced neutrophil accumulation and TNF- $\alpha$ has been shown with the small molecule agonist BMS-4705239 from the group at Bristol-Myers Squib directed against MC1R [26]. Utilising the pan-agonist $\alpha-M S H$ and selective MC3R agonist D-TRP $\left.{ }^{8}\right]-\gamma-M S H$ in this non-allergic model of inflammation similar responses were observed suggesting a role for both MCR peptides in this model.

We have demonstrated that melanocortins are potent anti-inflammatory agents in allergic and non-allergic models of lung inflammation model. These peptides inhibited eosinophil, lymphocyte accumulation in the allergic model, whilst in the nonallergic model, neutrophil accumulation and TNF- $\alpha$ levels were reduced. Further studies are required to ascertain the effect on bronchial hyperresponsiveness, although further evaluation of the biological effects of the melanocortin peptides directed towards the MC3R agonists is warranted as they may have the potential to be novel therapeutics for modulating lung inflammation. 


\section{Acknowledgements}

Research was funded by Research Advisory Board, Bart's and the London. We are also indebted to $\mathrm{Dr} \mathrm{H}$ Chen (Merck Research Laboratories, Rahway, NJ) for donating the founders of the MC3R mouse colony. 


\section{References}

[1] Ley K, Laudanna C, Cybulsky ML, Nourshagh S. Getting to the site of inflammation: the leukocyte adhesion cascade updates. Nat Rev Immunol 2007; 7: 678-689.

[2] Gilroy DW, Lawerence T, Perretti M, Rossi AG. Inflammatory resolution: new opportunities for drug discovery. Nat Rev Drug Discov 2004; 3: 401-416.

[3] Leoni G, Patel HB, Sampaio ALF, Gavins FN, Murray JF, Grieco P, Getting SJ, Perretti M. Inflamed phenotype of the mesenteric microcirculation of melanocortin type 3 receptor-null mice after ischemia-reperfusion. FASEB J. 2008. [Epub ahead of print].

[4] Barthel SR, Johansson MW, McNamee DM, Mosher DF. Roles of integrin activation in eosinophil function and the eosinophilic inflammation of asthma. $\mathrm{J}$ Leukoc Biol 2008; 83: 1-12.

[5] Riffo-Vasquez Y, Spina D, Page C, Tormay P, Singh M, Henderson B, Coates A. Effect of Mycobacterium tuberculosis chaperonins on bronchial eosinophilia and hyper-responsiveness in a murine model of allergic inflammation. Clin Exp Allergy $2004 ; 34: 712-719$.

[6] Perretti M. Endogenous mediators that inhibit leukcoyte-endothelium interaction. Trends in Pharmacol Sci 1997; 18: 418-425.

[7] Norling LV, Sampaio ALF, Cooper D, Perretti M. Inhibitory control of endothelial galectin-1 on in vitro and in vivo lymphocyte trafficking. FASEB J. 2008; 22: 682-690. [8] Serhan CN, Chiang N, Van Dyke TE. Resolving inflammation: dual antiinflammatory and pro-resolution lipid mediators. Nat Rev Immunol 2008; 8:349-361. [9] Catania A, Gatti S, Colombo G, Lipton JM. Targeting melanocortin receptors as a novel strategy to control inflammation. Pharmacol Rev 2004; 56: 1-29. 
[10] Getting SJ. Targeting melanocortin receptors as potential novel therapeutics. Pharmacol Ther 2006; 111: 1-15.

[11] Wikberg JE, Muceniece R, Mandrika I, Prusis P, Lindblom J, Post C, Skottner A. New aspects on the melanocortins and their receptors. Pharmacol Res 2000; 42: 393-420.

[12] Getting SJ, Gibbs L, Clark AJ, Flower RJ, Perretti M. POMC gene-derived peptides activate melanocortin type 3 receptor on murine macrophages, suppress cytokine release, and inhibit neutrophil migration in acute experimental inflammation. J Immunol 1999; 162: 7446-7453.

[13] Getting SJ, Allcock GH, Flower R, Perretti M. Natural and synthetic agonists of the melanocortin receptor type 3 possess anti-inflammatory properties. J Leukoc Biol 2001; 69: 98-104.

[14] Getting SJ, Christian HC, Lam CW Gavins FN, Flower RJ, Schioth HB, Perretti M. Redundancy of a functional melanocortin 1 receptor in the anti-inflammatory actions of melanocortin peptides: studies in the recessive yellow (e/e) mouse suggest an important role for melanocortin 3 receptor. J Immunol 2003; 170: 33233330.

[15] Rajora N, Boccoli G, Catania A, Lipton JM. $\alpha-M S H$ modulates experimental inflammatory bowel disease. Peptides 1997; 18: 381-385.

[16] Getting SJ, Christian HC, Flower RJ, Perretti M. Activation of melanocortin type 3 receptor as a molecular mechanism for adrenocorticotropic hormone efficacy in gouty arthritis. Arthritis Rheum 2002; 46: 2765-2775.

[17] Ceriani G, Diaz J, Murphree S, Catania A, Lipton JM. The neuropeptide alphamelanocyte-stimulating hormone inhibits experimental arthritis in rats. Neuroimmunomodulation 1994; 1: 28-32. 
[18] Lipton JM, Catania A, Ichiyama T. Marshaling the Anti-Inflammatory Influence of the Neuroimmunomodulator alpha-MSH. News Physiol Sci 2000; 15: 192-195.

[19] Raap U, Brzoska T, Sohl S, Path G, Emmel J, Herz U, Braun A, Luger T, Renz, H. Alpha-melanocyte-stimulating hormone inhibits allergic airway inflammation. J Immunol 2003; 171: 353-359.

[20] Manna SK, Aggarwal BB. $\alpha$-Melanocyte stimulating hormone inhibits the nuclear transcription factor NF-kB activation by various inflammatory agents. J. Immunol 1998; 161: 2873-2880.

[21] Kalden DH, Scholzen T, Brzoska T, Luger TA. Mechanisms of the antiinflammatory effects of alpha-MSH. Role of transcription factor NF-kappa B and adhesion molecule expression. Ann N Y Acad Sci 1999; 885: 254-261.

[22] Lam CW, Getting SJ, Perretti, M. In vitro and in vivo induction of heme oxygenase 1 in mouse macrophages following melanocortin receptor activation. $\mathrm{J}$ Immunol 2005; 174: 2297-2304.

[23] Lam CW, Perretti M, Getting SJ. Melanocortin receptor signaling in RAW264.7 macrophage cell line. Peptides 2006; 27: 404-412.

[24] Getting SJ, Lam CW, Chen AS, Grieco P, Perretti M. Melanocortin 3 receptors control crystal-induced inflammation. Faseb J. 2006; 20: 2234-2241.

[25] Grieco P, Balse PM, Weinberg D, MacNeil T, Hruby VJ. D-Amino acid scan of gamma-melanocyte-stimulating hormone: importance of $\operatorname{Trp}(8)$ on human MC3 receptor selectivity. J Med Chem 2000; 43: 4998-5002.

[26] Kang L, McIntyre KW, Gillooly KM, Yang Y, Haycock J, Roberts S, Khanna A, Herpin TF, Yu G, Wu X, Morton GC, Tuerdi H, Koplowitz B, Walker SG, WardellSwanson J, Macor JE, Lawerence RM, Carlson KE. A selective small molecule 
agonist of the melanocortin-1 receptor inhibits lipopolysaccharide-induced cytokine accumulation and leukocyte infiltration in mice. J Leukoc Biol 2006; 80: 897-904.

[27] Pitchford SC, Riffo-Vasquez Y, Sousa A, Momi S, Gresele P, Spina D, Page CP. Platelets are necessary for airway wall remodeling in a murine model of chronic allergic inflammation. Blood 2004; 103: 639-647.

[28] Chen AS, Marsh DJ, Trumbauer ME, Frazier EG, Guan XM, Yu H, Rosenblum Cl, Vongs A, Feng Y, Cao L, Metzger JM, Strack AM, Camacho RE, Mellin TN, Nunes CN, Min W, Fisher J, Gopal-Truter S, Maclntyre DE, Chen HY, Van der Ploeg LH. Inactivation of the mouse melanocortin-3 receptor results in increased fat mass and reduced lean body mass. Nat Genet 2000; 26: 97-102.

[29] Riffo-Vasquez Y, Spina D, Thomas M, Gilbey T, Kemeny DM, Page CP. The role of CD23 on allergen-induced IgE levels, pulmonary eosinophilia and bronchial hyperresponsiveness in mice. Clin Exp Allergy 2000; 30: 728-738.

[30] Berry D, Lindgren B: Statistics: Theory and methods 1990.

[31] Butler AA, Kesterson RA, Khong K, Cullen MJ, Pelleymounter MA, Dekoning J, Baetscher M, Cone RD. A unique metabolic syndrome causes obesity in the melanocortin-3 receptor-deficient mouse. Endocrinology 2000; 141: 3518-3521.

[32] Caruso C, Durand D, Schioth HB, Rey R, Seilicovich A, Lasaqa M. Activation of melanocortin 4 receptors reduces the inflammatory response and prevents apoptosis induced by lipopolysaccharide and interferon-gamma in astrocytes. Endocrinology 2007; 148: 4918-4926.

[33] Catania A, Cutuli M, Garofalo L, Carlin A, Airaghi L, Barcellini W, Lipton JM. The neuropeptide alpha-MSH in host defense. Ann N Y Acad Sci 2000; 917: 227-231. 
[34] Foster PS, Hogan SP, Ramsay AJ, Matthaei KI, Young IG. Interleukin 5 deficiency abolishes eosinophilia, airways hyperreactivity, and lung damage in a mouse asthma model. J Exp Med 1996; 183: 195-201.

[35] Webb TJ, Sumpter TL, Thiele AT, Swanson KA, Wilkes DS. The phenotype and function of lung dendritic cells. Crit Rev Immunol 2005; 25: 465-491. 
Table 1. cAMP accumulation in alveolar macrophages.

\begin{tabular}{cccc}
\hline Treatment & Concentration & Recessive yellow & MC3R null \\
& 0 & e/e & \\
\hline PBS & $3 \mu \mathrm{M}$ & $312 \pm 45$ & $73 \pm 8$ \\
Forskolin & 1 & $63 \pm 9$ & $309 \pm 26$ \\
[D-TRP ${ }^{8}-\gamma-\mathrm{MSH}$ & 3 & $180 \pm 20 *(+164 \%)$ & $71 \pm 21$ \\
& 10 & $110 \pm 13$ & $83 \pm 14$ \\
& 30 & $66 \pm 21$ & $70 \pm 8$ \\
$\alpha-\mathrm{MSH}$ & 1 & $89 \pm 17$ & $73 \pm 12$ \\
& 3 & $105 \pm 16$ & $74 \pm 7$ \\
& 10 & $143 \pm 20 *(+110 \%)$ & $83 \pm 18$ \\
& 30 & $210 \pm 15 *(+208 \%)$ & $82 \pm 23$ \\
\hline
\end{tabular}

Alveolar macrophages were incubated for 30 min with PBS, $\alpha-\mathrm{MSH}(1-30 \mu \mathrm{g} / \mathrm{ml})$, [D$\left.\mathrm{TRP}^{8}\right]-\gamma-\mathrm{MSH}(1-30 \mu \mathrm{g} / \mathrm{ml})$ or forskolin $(3 \mu \mathrm{M}$, used as a positive control) and cAMP accumulation determined using a commercially available EIA. Data are mean \pm SEM of 3 experiments, ${ }^{*} P<0.05$. Values in parenthesis represent percentage increase in CAMP levels above that which was observed in the presence of PBS only. 
Table 2. IL-5 (pg/ml) levels in BAL fluid.

\begin{tabular}{cccc}
\hline Treatment & WT & Recessive yellow e/e & MC3R null \\
\hline SHAM & $0 \pm 0$ & $0 \pm 0$ & $0 \pm 0$ \\
OVA & $33.2 \pm 2.7$ & $38.6 \pm 3.7$ & $42.1 \pm 3.6$ \\
\hline Dex $2.5 \mathrm{mg} / \mathrm{kg}$ & $33.2 \pm 2.7$ & $40.0 \pm 9.0$ & $40.1 \pm 2.6$ \\
\hline$\alpha-\mathrm{MSH} 1 \mathrm{mg} / \mathrm{kg}$ & $31.6 \pm 4.7$ & n.t. & n.t \\
$\alpha-\mathrm{MSH} 5 \mathrm{mg} / \mathrm{kg}$ & $30.4 \pm 2.4$ & $37.1 \pm 4.5$ & $39.6 \pm 2.4$ \\
\hline$\left[\mathrm{D}-\mathrm{TRP} \mathrm{P}^{8}\right]-\gamma-\mathrm{MSH}$ & $33.0 \pm 1.6$ & $38.4 \pm 9.1$ & n.t \\
$1 \mathrm{mg} / \mathrm{kg}$ & & & n.t \\
{$\left[\mathrm{D}-\mathrm{TRP}{ }^{8}\right]-\gamma-\mathrm{MSH}$} & $32.8 \pm 3.6$ & n.t. & \\
$5 \mathrm{mg} / \mathrm{kg}$ & & & \\
\hline
\end{tabular}

Mice were pre-treated i.p. with $\alpha-\mathrm{MSH}$ ( 1 or $5 \mathrm{mg} / \mathrm{kg}$ ), [D-TRP $\left.{ }^{8}\right]-\gamma-\mathrm{MSH}$ (1 or 5 $\mathrm{mg} / \mathrm{kg}$ ), dexamethasone (Dex) $(2.5 \mathrm{mg} / \mathrm{kg})$ or sterile saline, 5 min prior to $25 \mathrm{mins}$ OVA ( $3 \%$ in saline) exposure on days 14,15 and 16 . Bronchoalveolar lavage fluid was collected 24h (day 17) after final OVA exposure and IL-5 levels (pg/ml) determined by ELISA. Data are mean \pm SEM of $n=5$ mice per group. 


\section{Legends to the Figures}

Figure 1. Detection of MC1R and MC3-R protein in alveolar macrophages and brain. Panel a: MC1R and MC3R protein detection from C57 BI.6 mouse alveolar macrophages (Mac) and brain (+ve control), buffer (-ve control) (Data is representative of three experiments). Panel b: Densitometry analysis for determination of Mac MCR1 and 3R expression vs. +ve control. Data expressed as mean of 3 experiments.

Figure 2. Detection of MCR functionality. C57 BI.6 alveolar macrophages were incubated with $\alpha-\mathrm{MSH}\left(1-30 \mu \mathrm{g} / \mathrm{ml}\right.$, closed square), [D-TRP $\left.{ }^{8}\right]-\gamma-\mathrm{MSH}(1-30 \mu \mathrm{g} / \mathrm{ml}$, closed circle) or MS05 (1-30 $\mu \mathrm{g} / \mathrm{ml}$, open circle) and cell-associated cAMP determined at the 30 min time-point. Cell incubation with forskolin $(3 \mu \mathrm{M}$, used as positive control) led to $272 \pm 61$ fmol cAMP per well $(n=5)$. Data expressed as mean \pm SEM of 3 experiments. Dotted line refers to basal cAMP levels in unstimulated cells. ${ }^{*} \mathrm{P}<0.05$ vs. basal.

Figure 3: Effect of $\alpha-\mathrm{MSH}$ and $\left[\mathrm{D}-\mathrm{TRP}^{8}\right]-\gamma-\mathrm{MSH}$ on eosinophil and lymphocyte infiltration in BAL fluid of OVA challenged C57 BI.6 mice. Mice were pre-treated i.p. with $\alpha-\mathrm{MSH}$ (1 or $5 \mathrm{mg} / \mathrm{kg}$ ), [D-TRP $\left.{ }^{8}\right]-\gamma-\mathrm{MSH}$ (1 or $5 \mathrm{mg} / \mathrm{kg}$ ), dexamethasone (2.5 $\mathrm{mg} / \mathrm{kg}$ ) or sterile saline, 5 min prior to 25 mins OVA ( $3 \%$ in saline) exposure on days 14, 15 and 16. No eosinophils (Panel a) or lymphocytes (Panel b) were enumerated in bronchoalveolar lavage fluid from sham-immunized mice collected $24 \mathrm{~h}$ (day 17) after final OVA exposure. Data are mean \pm SEM of $n=5$ mice per group. * $P<0.05$ vs. OVA group. 
Figure 4: Effect of $\alpha-M S H$ and $\left[D^{-T R P}{ }^{8}\right]-\gamma-M S H$ on eosinophil and lymphocyte infiltration in BAL fluid of OVA challenged recessive yellow e/e (mutant MC1R) mice. Mice were pre-treated i.p. with $\alpha-\mathrm{MSH}(5 \mathrm{mg} / \mathrm{kg})$, [D-TRP $\left.{ }^{8}\right]-\gamma-\mathrm{MSH}(1 \mathrm{mg} / \mathrm{kg})$, dexamethasone $(2.5 \mathrm{mg} / \mathrm{kg}$ ) or sterile PBS, $5 \mathrm{~min}$ prior to $25 \mathrm{mins}$ OVA ( $3 \%$ in saline) exposure on days 14, 15 and 16. No eosinophils (Panel a) or lymphocytes (Panel b) were enumerated in bronchoalveolar lavage fluid from sham-immunized mice collected $24 \mathrm{~h}$ (day 17) after final OVA exposure. Data are mean \pm SEM of $n=5$ mice per group. ${ }^{*} \mathrm{P}<0.05$ vs. OVA group.

Figure 5: Effect of $\alpha-\mathrm{MSH}$ on eosinophil and lymphocyte infiltration in BAL fluid of OVA challenged MC3R null mice. Mice were pre-treated i.p. with $\alpha-M S H$ (5 mg/kg), dexamethasone $(2.5 \mathrm{mg} / \mathrm{kg}$ ) or sterile PBS, 5 min prior to $25 \mathrm{mins}$ OVA (3\% in saline) exposure on days 14, 15 and 16. No eosinophils (Panel a) or Lymphocytes (Panel b) were enumerated in bronchoalveolar lavage fluid from shamimmunized mice collected $24 \mathrm{~h}$ (day 17 ) after final OVA exposure. Data are mean \pm SEM of $n=5$ mice per group. ${ }^{*} P<0.05$ vs. OVA group.

Figure 6: Effect of $\alpha-\mathrm{MSH}$ and $\left[\mathrm{D}-\mathrm{TRP}^{8}\right]-\gamma-\mathrm{MSH}$ on neutrophil accumulation in BAL fluid of LPS challenged mice. Mice were pre-treated i.p. with $\alpha-\mathrm{MSH}$ ( $5 \mathrm{mg} / \mathrm{kg}$ i.p.), [D-TRP ${ }^{8}$ ]- $\gamma-\mathrm{MSH}$ (1 mg/kg i.p.) or sterile saline (0.2ml i.p.), $60 \mathrm{~min}$ prior to $50 \mu \mathrm{l}$ intranasal LPS $(10 \mu \mathrm{g} / \mathrm{ml})$. Number of neutrophils (Panel a) and TNF- $\alpha$ levels (Panel b) were enumerated in bronchoalveolar lavage fluid $4 \mathrm{~h}$ after challenge. Data are mean \pm SEM of $n=6$ mice per group. ${ }^{*} P<0.05$ vs. saline group. 
Figure 1

a

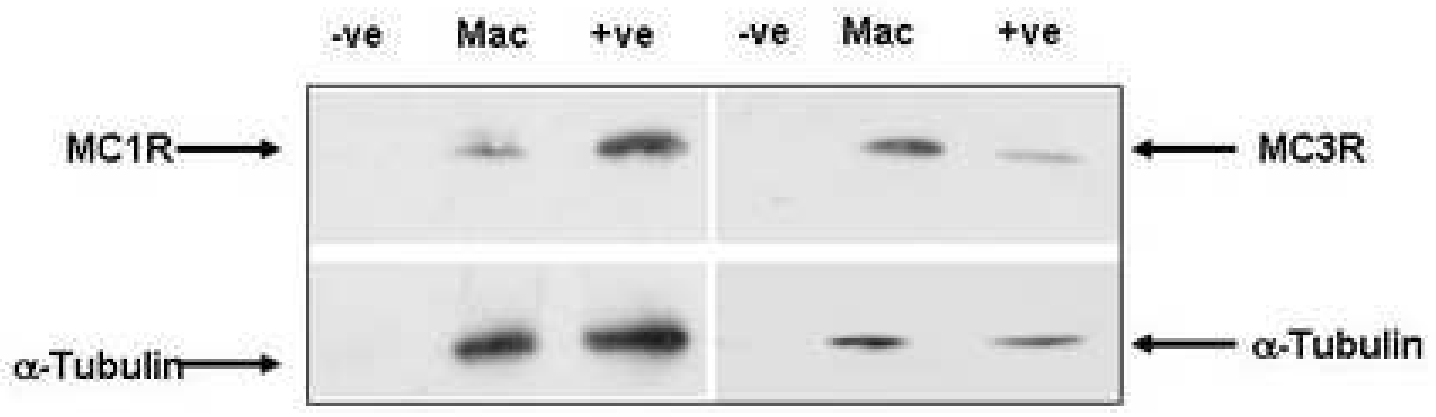

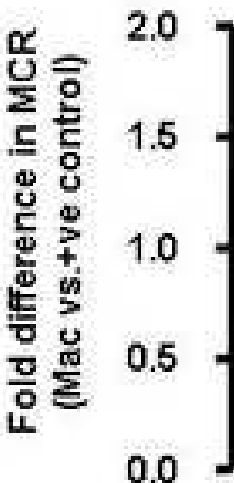

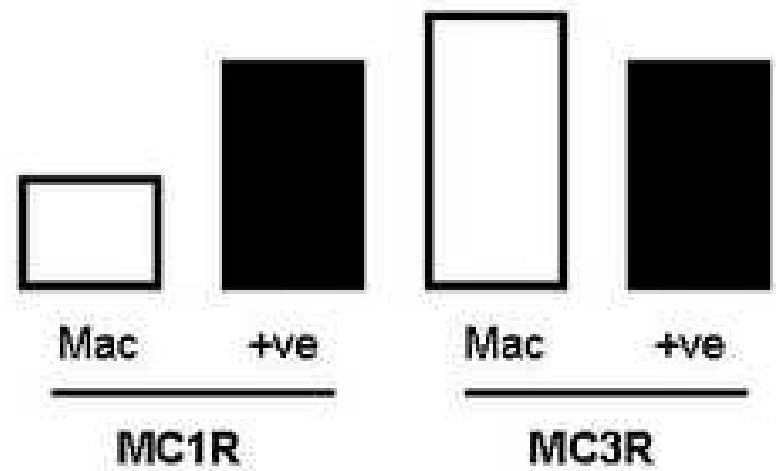


Figure 2

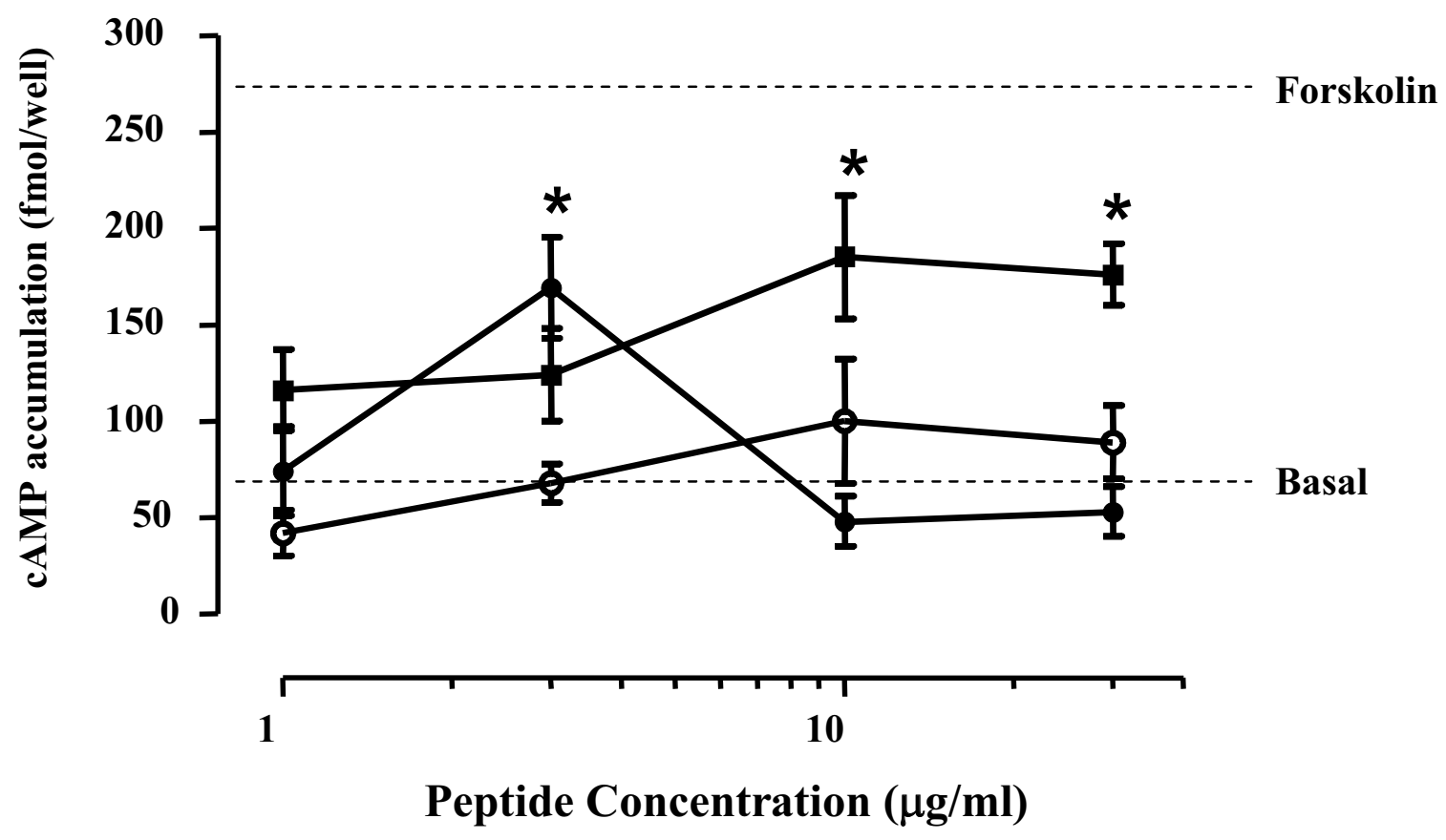


Figure 3

a
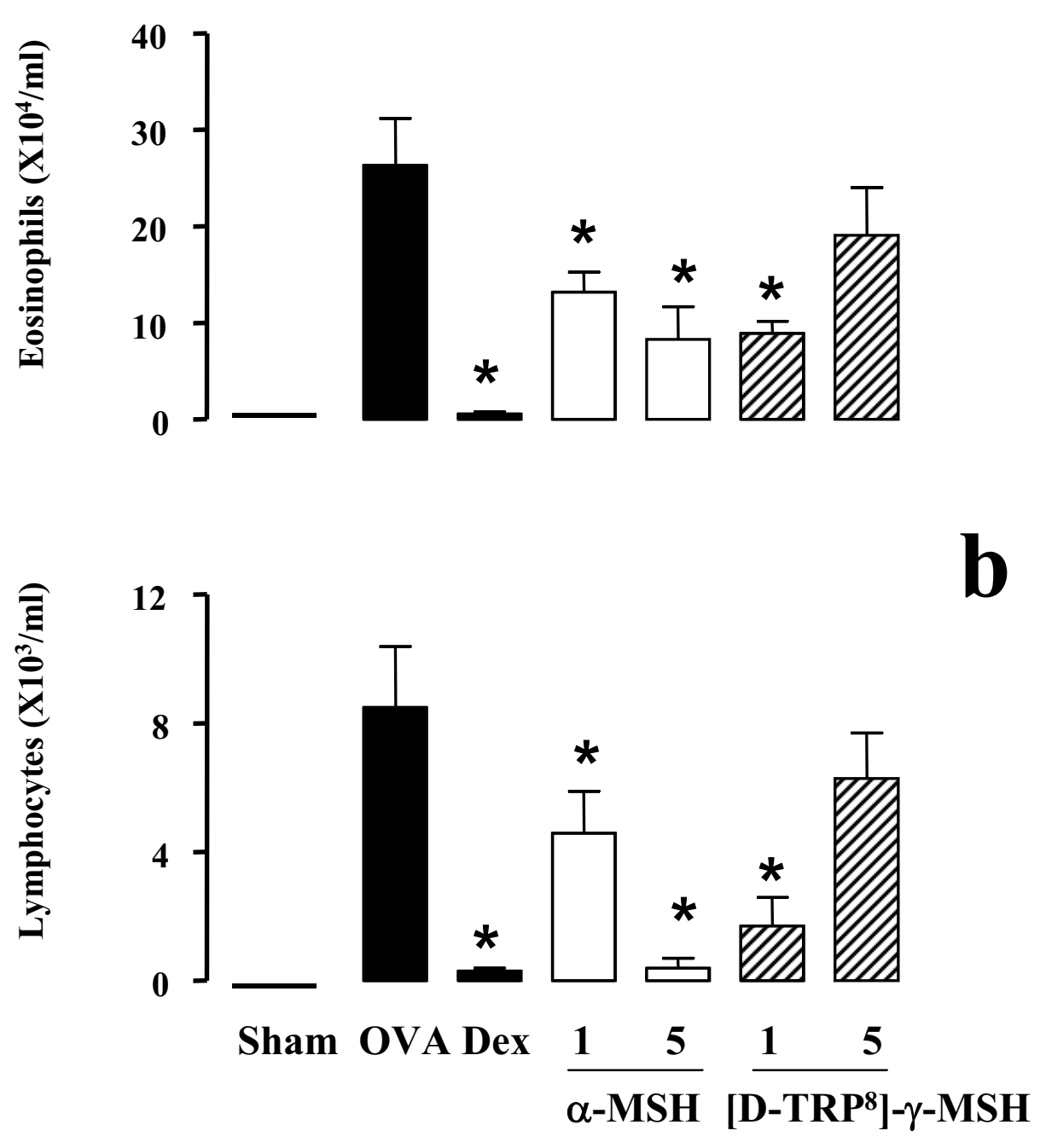
Figure 4

a
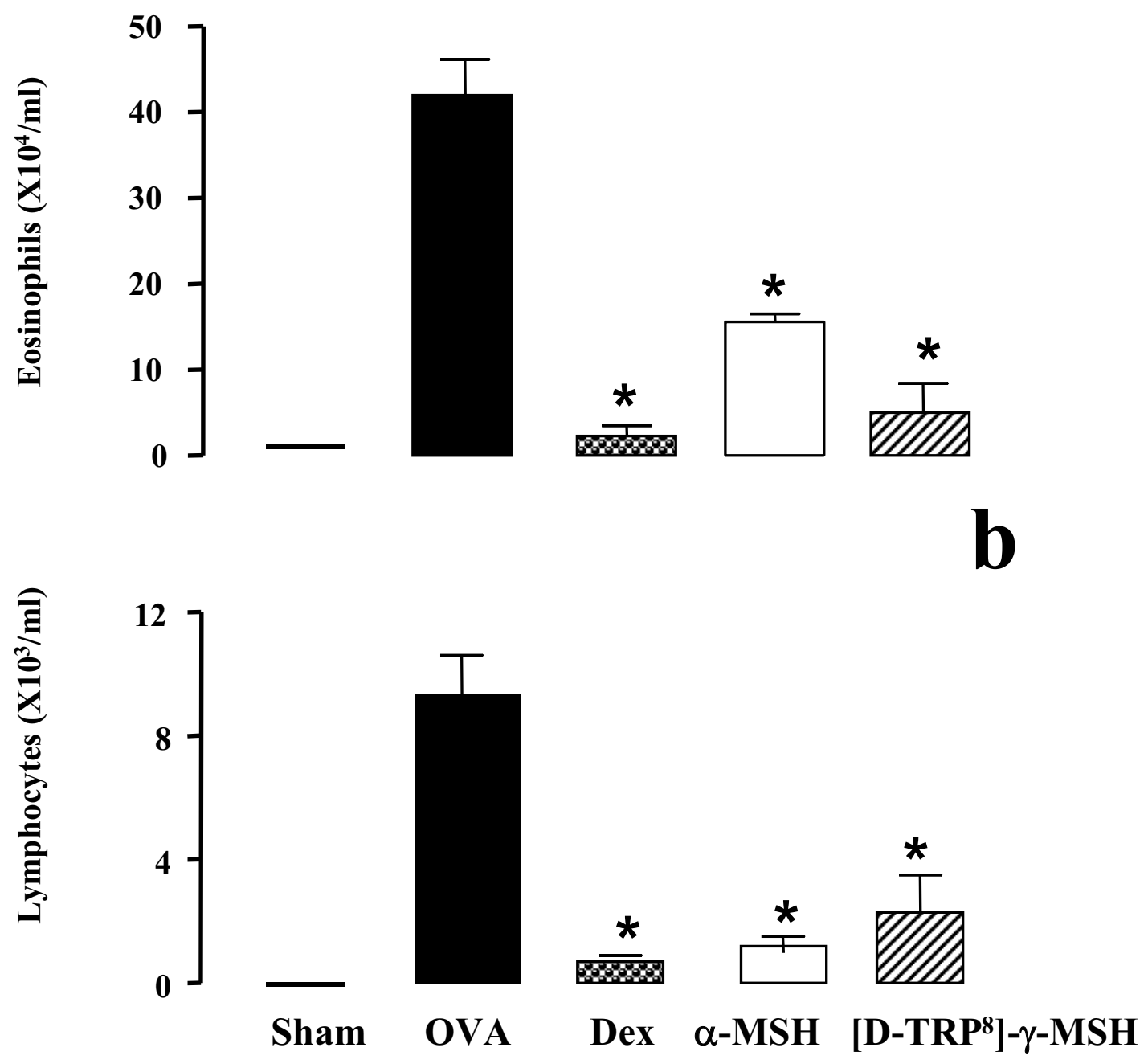
Figure 5

$\mathbf{a}$
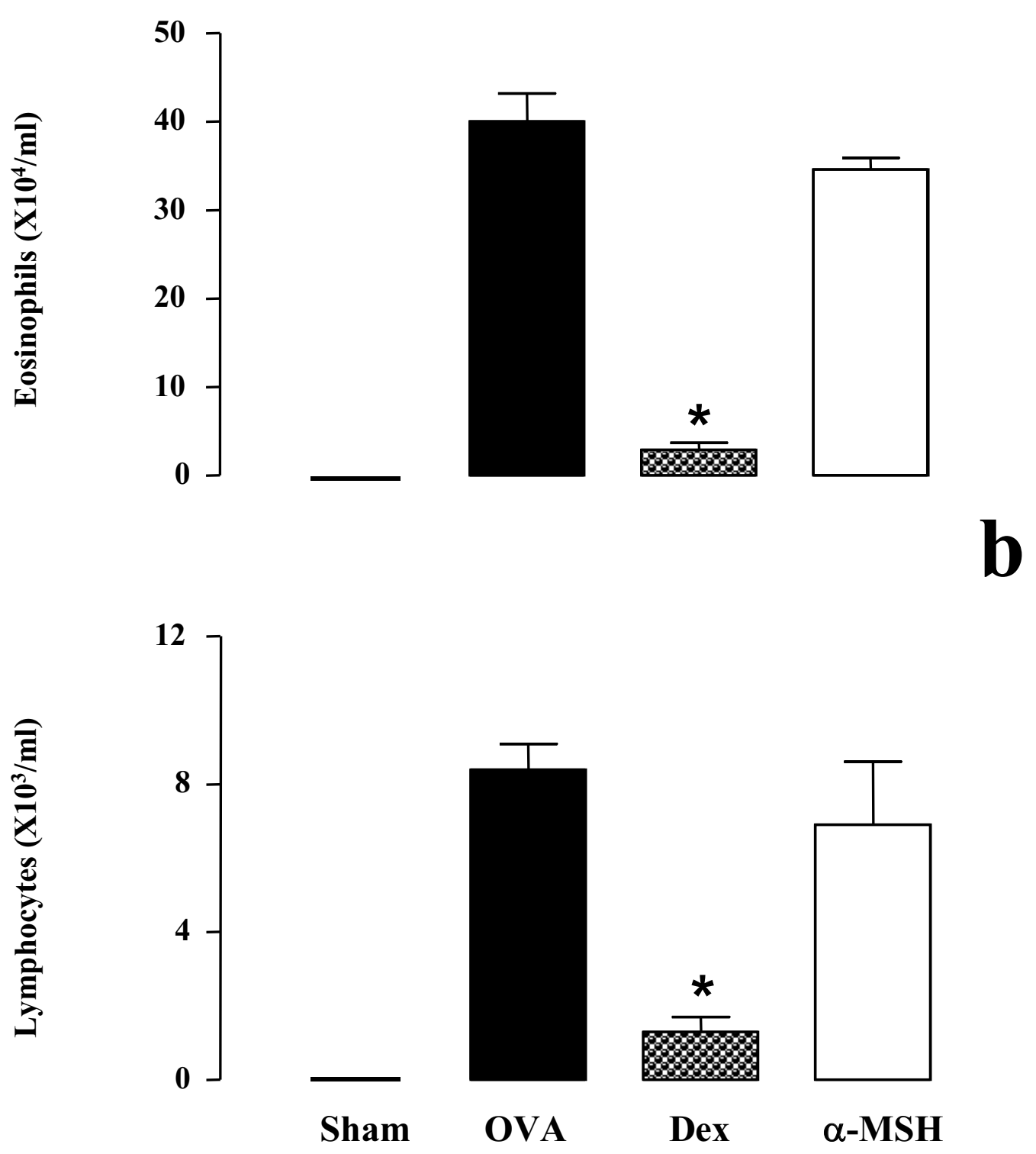
Figure 6

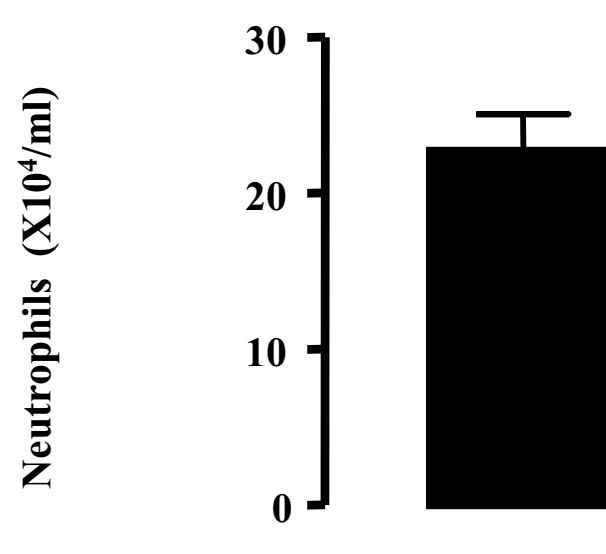

a

b

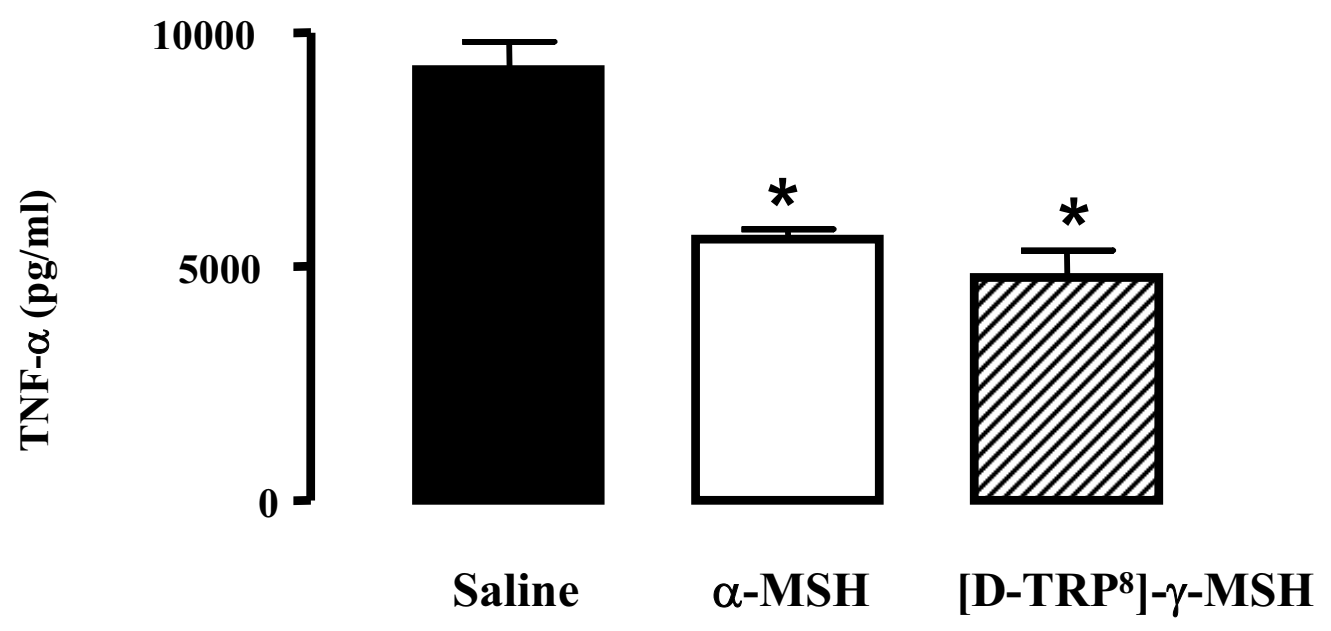

